\title{
МЕТОДИЧНІ ЗАСАДИ ЗАСТОСУВАННЯ ЛОГІСТИЧНОГО УПРАВЛІННЯ В ПРОЦЕСІ ЗАБЕЗПЕЧЕННЯ ЕКОНОМІЧНОЇ БЕЗПЕКИ ПІДПРИЕМСТВА
}

\author{
А. М. ШТАНГРЕТ \\ доктор економічних наук, професор, \\ Українська академія друкарства \\ Л. П. СТЕЦІВ \\ кандидат економічних наук, доцент, \\ Українська академія друкарства
}

\begin{abstract}
Анотація. Мета статті полягає в обтрунтуванні методичних засад застосування логістичного управління в прочесі забезпечення економічної безпеки українських підприємств, зокрема щзодо удосконалення обліково-аналітичного забезпечення. Методика дослідження. Досягнення поставленої у статті мети здійснено за допомогою таких методів дослідження, як абстрактно-логічний метод, методи індукиї та дедукиії, порівняння і систематизації, синтезу і аналізу, морфологічного аналізу. Результати. Обтрунтовано роль інформаційних ресурсів в процесі забезпечення економічної безпеки підприємства та визначено критерії, яким повинна відповідати інформація. Зазначено базові умови формування інформаційного забезпечення для суб'єктів безпеки. Розглянуто та критично охарактеризовано сутність ключових підходів до трактування терміна «логістичне управління». Окреслено методичні засади застосування логістичного управління в процесі удосконалення обліково-аналітичного забезпечення системи економічної безпеки підприємства. Практична значущість результатів дослідження. Застосування на практиці сформованих методичних засад сприятиме подальшому удосконаленню системи економічної безпеки в умовах кожного суб 'єкта господарювання.
\end{abstract}

Ключові слова: економічна безпека підприємства, логістичне управління, інформація, обліково-аналітичне забезпечення, безпека, загроза.

Постановка проблеми в загальному вигляді та її зв'язок із найважливішими науковими чи практичними завданнями. Невизначеність, яка є наслідком високої динаміки середовища функціонування, суттєво ускладнює процес функціонування українських підприємств. Нездатність сформувати не лише стратегічні, але подекуди й тактичні плани не сприяє ефективному використанню наявних ресурсів, реалізації інноваційних проєктів, розширенню присутності на ринку, що загалом спричиняе поступову втрату конкурентоспроможності та збільшує ймовірність банкрутства. Певним стабілізатором, який дає змогу частково реагувати на зміну середовища функціонування та пристосовуватися до них, виступає система економічної безпеки підприємства. Водночас і сама така система повинна як враховувати особливості ведення фінансово-господарської діяльності певного підприємства, так і бути здатною виявляти внутрішні та зовнішні виклики, ризики та загрози, а також протидіяти ним. Сьогодні такі системи лише частково виконують поставлені завдання через відсутність достатнього досвіду та теоретичних розробок. Отже, актуальними $є$ подальші дослідження, орієнтовані на вдосконалення системи економічної безпеки як ключової умови функціонування та розвитку кожного підприємства.
Аналіз останніх досліджень i публікацій. Теоретичному розробленню питань, пов'язаних із забезпеченням економічної безпеки на всіх рівнях управління, багато уваги приділяли О. Ареф'єва, С. Барановський [3], В. Білоус, І. Бінько, Н. Вавдіюк, В. Геєць, 3. Герасимчук, У. Детмар [1], В. Духов, М. Єрмошенко, Я. Жаліло, Т. Кузенко, О. Кузьмін, А. Кірієнко, С. Мочерний, В. Мунтіян, Н. Нижник, Г. Пастернак-Таранушенко, С. Покропивний, П. Пушкар [6], О. Терещенко, В. Франчук, С. Шкарлет, В. Шлемко, Е. Шрагенхайм [1], В. Ярочкін.

Сутність логістичного підходу в управлінні обгрунтували такі вчені, як М. Долішній, В. Кацьма [2], Є. Крикавський, Р. Ларіна, Б. Паласюк [5], Л. Фролова.

Віддаючи належне науковій та практичній значущості праць згаданих учених, маємо зазначити, що у вітчизняній і зарубіжній літературі досі не знайшли належного відображення деякі важливі аспекти забезпечення економічної безпеки підприємства, зокрема щодо здійснення управління на основі логістичного підходу.

Формування цілей статті (постановка завдання). Мета статті полягає в обгрунтуванні методичних засад застосування логістичного управління в процесі забезпечення економічної безпеки українських підприємств, зокрема щодо удосконалення обліково-аналітичного забезпечення. 
Виклад основного матеріалу дослідження 3 повним обгрунтуванням отриманих наукових результатів. Рівень економічної безпеки підприємства, який уможливлює високу ефективність фінансово-господарської діяльності та реалізацію корпоративних інтересів, залежить від здатності суб'єктів безпеки своєчасно реагувати на зміни внутрішньогосподарських процесів та відстежувати динаміку зовнішнього середовища. В основі дій суб'єктів безпеки лежить робота 3 інформацією. Можна стверджувати, що забезпечення економічної безпеки передбачає переважно застосування двох ресурсів, а саме людських та інформаційних. Інші, тобто фінансові й матеріальні, відіграють менш важливу роль. В межах цього дослідження увагу буде зосереджено саме на інформації як основи прийняття управлінських рішень.

Попри значну кількість визначень терміна «інформація», на нашу думку, доцільно виділити позицію М. Пушкаря, який подає його сутність як «субстрат, необхідний і обов'язковий для того, щоб оцінити ситуацію, виробити можливі альтернативи управлінських рішень та відібрати найдоцільніші 3 них для практичного використання» [6, с. 59]. В цьому визначенні з позиції забезпечення економічної безпеки акцентується увага на двох моментах: по-перше, йдеться про узагальнення даних і відомостей $з$ різних джерел для формування шляхом поєднання, узагальнення, перевірки та доповнення, уявлення про певне явище чи процес; по-друге, сформоване інформаційне підгрунтя дає змогу зменшити невизначеність, отже, знизити рівень ризику, тобто сприяє підтриманню безпеки. Водночас не можна відкидати дещо іншу позицію, прихильниками якої $є$ У. Детмар та Е. Шрагенхайм, сутність якої зводиться до твердження, що «інформація являє собою палицю 3 двома кінцями: без неї не можна приймати ефективного рішення, але іiі надлишок сповільняє процес» [1, с. 241]. Складно не погодитися 3 цим фактом, адже, окрім збільшення тривалості підготовчих процедур, витрати на отримання й опрацювання додаткової одиниці інформації можуть бути більшими за можливі втрати в разі реалізації певної загрози, що знижує ефективність дій суб'єктів безпеки. Відповідно, можна стверджувати, що задля забезпечення економічної безпеки інформація повинна відповідати таким критеріям, як достовірність (відображення дійсного стану й перебігу подій), своєчасність (оперативне отримання відомостей і даних), комплексність (надходження з різних джерел для перевірки та доповнення), доцільність (концентрація ресурсів на роботу з цієї інформацією, яка є затребуваною в певній ситуації) та раціональність (витрати не можуть бути більшими за можливі втрати).
Доцільно наголосити на тому, що в процесі забезпечення економічної безпеки інформація $\epsilon$ основою не лише прийняття будь-яких рішень, але й оцінювання рівня безпеки та моніторингу динамічності зовнішнього середовища. Зазначене доводить важливість інформації, отже, вимагає в межах кожного підприємства створення системи обліково-аналітичного забезпечення. В контексті зазначеного доцільно підкреслити, що С. Барановський розуміє систему обліково-аналітичного забезпечення «як таку, що грунтується на даних оперативного, статистичного, фінансового і управлінського обліку, включаючи оперативні дані, і використовує для економічного аналізу статистичну, виробничу, довідкову та інші види інформації» [3, с. 9]. В цьому визначенні відзначається, що в основі такої системи лежить процедура збирання облікових даних і відомостей із подальшим їх аналізом. Загалом погоджуючись із таким підходом, вважаємо, що з позиції забезпечення економічної безпеки інформація повинна проходити обов'язкову перевірку, до якої доцільно долучити аудиторів та аналітиків, із узгодженням та формуванням уявлень про цілісність і достатність для прийняття управлінських рішень. Іншим ключовим моментом $\epsilon$ той факт, що така система обліково-аналітичного забезпечення, яка орієнтована на задоволення потреб суб'єктів безпеки, повинна бути інтегрованою в загальну систему обліково-аналітичного забезпечення, яка використовується для досягнення цілей управління підприємством. Існування двох незалежних систем $є$ нераціональним витрачанням ресурсів, а їх поєднання складно реалізується в межах застосування традиційних методів управління. Базові умови формування обліковоаналітичного забезпечення в системі економічної безпеки підприємства можна окреслити таким чином:

- об'єктом безпеки й найбільшим джерелом внутрішніх загроз виступають працівники підприємства;

- для потреб забезпечення економічної безпеки потрібен не весь обсяг інформації, а лише iii частина, яка вказує на ознаки викликів, ризиків i загроз, які можуть спричинити зміну рівня безпеки підприємства;

- інформація в межах процесу забезпечення економічної безпеки підприємства повинна передаватися $з$ дотримання режиму секретності;

- збір інформації для задоволення потреб суб'єктів безпеки не обмежується фінансовою сферою, а стосується усіх внутрішньогосподарських процесів та будь-яких змін зовнішнього середовища;

- наявність «інформаційного шуму» ускладнює процес відбору даних і відомостей, які безпосередньо потрібні суб'єктам безпеки, що вимагає 
використання додаткових ресурсів для перевірки та забезпечення високого рівня достовірності;

- своєчасна реакція через прийняття адекватних управлінських рішень, реалізація яких дасть змогу мінімізувати втрати або використати додаткові ринкові можливості, залежить від швидкості надходження інформації, отже, система обліковоаналітичного забезпечення повинна бути достатньо динамічною;

- оптимізація витрат на створення й функціонування системи обліково-аналітичного забезпечення можлива завдяки управлінню інформаційними потоками з удосконаленням організаційного забезпечення в межах системи економічної безпеки підприємства.

На нашу думку, вирішення цієї багатоаспектної проблеми, відповідно до окреслених базових умов, лежить у площині використання методичних засад логістичного управління. Доцільно зробити зауваження, що наша позиція передбачає використання методичних засад логістичного управління задля удосконалення системи економічної безпеки підприємства, зокрема підсистеми обліково-аналітичного забезпечення, а це вимагає розгляду сутності базових понять із подальшим виділенням цієї частини, яка придатна до застосування у сфері безпеки. Так, поняття «логістичне управління» не характеризується однозначністю в наукових колах і здебільшого прив'язано до процесу виробництва шляхом оптимізації ресурсного забезпечення. Лише іноді згадується інформація як ресурс, але ретельний розгляд цього аспекту відсутній. Прикладом такої позиції може бути визначення, яке міститься у монографії Р. Ларіної, О. Череп, І. Гришина та А. Ілаєвої, де логістичне управління подано як «процес або діяльність, яка підпорядкована наперед окресленим цілям, здійснюється у логічній послідовності, може бути організована на стратегічному та тактичному рівнях, здійснюється безперервно і включає планування, організацію, реалізацію та контроль товаропросування - руху сировини, матеріалів i напівфабрикатів, готової продукції (швидкості руху, об'ємів руху, адаптивності) на виробництво, у процесі виробництва та до споживача на основі формування логістичної системи товаропросування та логістичної сітки» [4, с. 39]. В основі цього визначення лежить стратегічне й тактичне управління матеріальними потоками, починаючи від постачальників, у межах виробництва і до споживачів продукції. Як загальна схема такий варіант прийнятний стосовно процесу забезпечення економічної безпеки підприємства. Якщо розглядати процес отримання, узагальнення, перевірки, аналізу й надання споживачам інформації, то застосування логістичного ланцюга є прийнятним.

Важливими $є$ інші, виділені нами чотири моменти. Перший полягає в тому, що логістичне управління орієнтовано на задоволення потреб споживачів, адже його також трактують як «процес формування стратегії, планування, управління й контролю за переміщенням і складуванням сировини, матеріалів, виробничих запасів, готових виробів та формуванням інформації від пункту виникнення до пункту використання (споживання) задля найефективнішого пристосування та задоволення потреб споживача» [4, с. 45]. 3 позиції забезпечення економічної безпеки підприємства споживачами першого рівня будуть співробітники служби безпеки, а другого - менеджери, для яких суб'єкти безпеки готують аналітичні довідки щодо інформаційного супроводу певних управлінських рішень задля мінімізації можливих втрат або отримання додаткової вигоди за рахунок врахування наявності й ступеня впливу внутрішніх і зовнішніх викликів, ризиків та загроз. Відповідно до логістичного управління, дії щодо задоволення інформаційних потреб цих груп споживачів повинні бути спланованими й здійснюватися за оптимізованим маршрутом по захищених каналах, що дасть змогу отримати інформацію, яка відповідає визначеним вище критеріям.

Другий момент - орієнтація на досягнення синергетичного ефекту, що чітко прослідковується у визначенні, що надає Б. Паласюк: «цілеспрямований вплив на логістичні потоки задля синхронізації їхньої взаємодії і досягнення ефекту синергізму» [5, с. 169]. Такий ефект може бути досягнутий шляхом чіткої організації змін у системі обліковоаналітичного забезпечення, коли, відповідно до розроблених інструкцій, працівники структурних підрозділів будуть виділяти певну частину інформації, яка представляє інтерес для суб'єктів безпеки і з чіткою періодичністю надсилати захищеними каналами інформації. Підсиленню цього ефекту сприятиме скерування проєкту ключових рішень на узгодження службі безпеки 3 огляду на те, що лише їі працівники, маючи цілісне уявлення про усі процеси, які відбуваються в межах підприємства і в його зовнішньому середовищі, можуть на певному рівні прогнозувати вплив результатів реалізації цих рішень на рівень безпеки. Прогнози щодо виникнення чи зміни впливу певної загрози стають основою превентивних захисних заходів, вжиття яких дасть змогу зменшити можливі втрати 3 мінімальним витрачанням ресурсів.

Третій момент - поєднання традиційно розрізнених інформаційних потоків у єдиний на постійній основи. Так, згадана група науковців доводить, що «раніше об'єктом управління були масові окремі матеріальні об'єкти, а за логістичного підходу основним об'єктом стає потік, тобто множина об'єктів, що сприймаються як ціле» [4, с. 39]. Налагодження надходження інформації від усіх структурних підрозділів на постійній основі забезпечує оперативність дій суб'єктів без- 
пеки, отже, високу ефективність у процесі підтримання необхідного рівня безпеки.

Четвертий момент - подолання спротиву 3 боку керівників окремих підрозділів щодо управління інформаційними потоками в межах їх сфери впливу. У разі систематичного надходження інформації до служби безпеки можуть бути виявлені прогалини в управлінні структурними підрозділами або зловживання з боку їх керівників, що провокує спротив.

В логістичному управлінні традиційно розрізняються такі підсистеми, як підсистеми «постачання, складська, транспортна, виробнича і збутова» [2, с. 62]. В системі обліково-аналітичного забезпечення такими підсистемами можуть бути підсистеми обліку, аудиту й аналізу, які відображають зміст основних етапів отримання, перевірки й аналізу інформації.

Б. Паласюк обгрунтовує, що «логістичне управління інвестиційною, інноваційною, виробничою, фінансовою, кадровою та інформаційною сферами діяльності сприяє реалізації стратегічних, а всіма потоковими процесами в ланцюзі «закупівля ресурсів - транспортування - виробництво - складування - реалізація - сервісне обслуговування кінцевих споживачів» - тактичних цілей підприємства» [5, с. 169]. Перш за все важливим $є$ те, що зазначений науковець суттєво розширює сферу застосування логістичного управління. Водночас поза увагою залишилася безпекова сфера, яка безпосередньо пов'язана 3 процесом забезпечення економічної безпеки підприємства.
Відповідно до вищезазначеного, загальну мету застосування методичних засад логістичного управління в забезпеченні економічної безпеки підприємства можна окреслити як формування системи отримання, перевірки й аналізу інформації, яка, відповідаючи визначеним критеріям (достовірність, комплексність, доцільність, раціональність) та отримуючись шляхом інтеграції в систему обліково-аналітичного забезпечення управління підприємством, формує необхідне підгрунтя для вжиття захисних заходів суб'єктами безпеки.

Висновки iз зазначених проблем i перспективи подальших досліджень у поданому напрямі. Поширення практики застосування методичних засад логістичного управління дасть змогу сформувати динамічну систему обліковоаналітичного забезпечення, яка уможливить здійснення своєчасного збирання якісної і необхідної за обсягом інформації з внутрішніх і зовнішніх джерел із подальшим узагальненням, систематизацією, аналізом, перевіркою на достовірність і зберіганням для повного задоволення потреб як суб'єктів безпеки, так і менеджменту підприємства для прийняття ними управлінських рішень 3 урахуванням безпекового аспекту.

В дослідженні зроблено лише першу спробу окреслити можливість застосування логістичного управління у сфері забезпечення безпеки на рівні окремого підприємства, тому важливим завданням $€$ подальше уточнення понятійного апарату та розроблення відповідної концепції.

\section{СПИСОК ВИКОРИСТАНИХ ДЖЕРЕЛ}

1.Детмер У., Шрагенхайм Е. Производство с невероятной скоростью: улучшение финансовых результатов предприятия. Москва : Альпина Паблишерз, 2009. 330 с.

2. Кацьма В. Сутність та роль логістичного управління в системі управління підприємством. Економічний аналіз. 2016. № 2. С. 60-65.

3. Менеджмент та підприємництво в Україні: етапи становлення і проблеми розвитку : збірник наук. праць / відп. ред. О. Кузьмін. Львів : вид-во Львівської політехніки, 2012. 256 с.

4. Моделі і методи логістичного управління суб’єктами господарювання й економікою регіону : монографія / Р. Ларіна, О. Череп, І. Грішин, А. Ілаєва. Сімферополь : ВД «АРІАЛ», 2011. 234 с.

5.Паласюк Б. Логістичне управління підприємством: сутність і основні принципи. Галицький економічний вісник. 2012. № 3 (36). С. 166-170.

6. Пушкар М. Креативний облік (створення інформації для менеджерів) : монографія. Тернопіль : Карт-бланш, 2006. $334 \mathrm{c}$.

\section{REFERENCES}

1.Detmer U., Shragenhaym E. (2009) Proizvodstvo s neveroyatnoy skorostyu: uluchshenie finansovyih rezultatov predpriyatiya [Manufacturing at blazing speed: improving your bottom line]. Moscow: Alpina Pablisherz. (in Russian)

2. Katsma V. (2016) Sutnist ta rol lohistychnoho upravlinnia v systemi upravlinnia pidpryiemstvom [The essence and role of logistics management in the enterprise management system]. Ekonomichnyi analiz [Economic analysis], no. 2, pp. 60-65. (in Ukrainian)

3. Kuzmin O. (2012) Menedzhment ta pidpryiemnytstvo v Ukraini: etapy stanovlennia i problemy rozvytku [Management and entrepreneurship in Ukraine: stages of formation and problems of development]. Lviv: vyd-vo Lvivskoi politekhniky. (in Ukrainian)

4.Larina R., Cherep O., Hrishyn I., Ilaieva A. (2011) Modeli i metody lohistychnoho upravlinnia subiektamy hospodariuvannia y ekonomikoiu rehionu [Models and methods of logistics management of economic entities and the economy of the region]. Simferopol: VD "ARIAL". (in Ukrainian) 
5. Palasiuk B. (2012) Lohistychne upravlinnia pidpryiemstvom: sutnist i osnovni pryntsypy [Logistic management of the enterprise: essence and basic principles]. Halytskyi ekonomichnyi visnyk [Galician Economic Bulletin], no. 3(36), pp. 166-170. (in Ukrainian)

6. Pushkar M. (2006) Kreatyvnyi oblik (stvorennia informatsii dlia menedzheriv) [Creative accounting (creating information for managers)]. Ternopil: Kart-blansh. (in Ukrainian)

А. М. Штангрет, Л. П. Стецив, Украинская академия печати. Методические основы применения логистического управления в процессе обеспечения экономической безопасности предприятия.

Аннотация. Цель статьи заключается в обосновании методических основ применения логистического управления в процессе обеспечения экономической безопасности украинских предприятий, в частности касательно совершенствования учетно-аналитического обеспечения. Методика исследования. Достижение поставленной в статье иели осуществлено с помощью таких методов исследования, как абстрактно-логический метод, методы индукиии и дедукции, сравнения и систематизации, синтеза и анализа, морфологического анализа. Результаты. Обоснована роль информационных ресурсов в процессе обеспечения экономической безопасности предприятия и определены критерии, которым должна соответствовать информация. Указаны базовые условия формирования информационного обеспечения для субъектов безопасности. Рассмотрена и критически охарактеризована сущзность ключевых подходов к трактовке термина «логистическое управление». Определены методические основы применения логистического управления в проиессе усовершенствования учетно-аналитического обеспечения системы экономической безопасности предприятия. Практическая значимость результатов исследования. Применение на практике сложившихся методических основ будет способствовать дальнейшему совершенствованию системь экономической безопасности в условиях каждого субъекта хозяйствования.

Ключевые слова: экономическая безопасность предприятия, логистическое управление, информация, учетно-аналитическое обеспечение, безопасность, угроза.

Andriy Shtangret, Lesya Stetsiv, Ukrainian Academy of Printing. Methodical bases of application of logistic management in the course of maintenance of economic safety of the enterprise.

Annotation. The purpose of the article is to substantiate the methodological principles of application of logistics management in the process of ensuring the economic security of Ukrainian enterprises, in particular in terms of improving accounting and analytical support. Methodology of research. Achieving the goal set in the article is carried out using the following research methods: induction and deduction, comparison and systematization - to study the essence of such concepts as "information", "accounting and analytical support" and "logistics management"; synthesis and analysis - to determine the criteria that must be met by the information used by security actors; morphological analysis - to outline the methodological principles of application of logistics management in the process of ensuring the economic security of the enterprise; abstract-logical-for theoretical generalizations and conclusions of the study. Findings. The role of information resources in the process of ensuring the economic security of the enterprise is substantiated and the criteria to be met by the information (reliability, complexity, expediency, rationality) are determined. The basic conditions for the formation of information support for security entities are indicated. The essence of key approaches to the interpretation of the term "logistics management" is considered and critically characterized. The methodical bases of application of logistic management in the course of perfection of accounting and analytical maintenance of system of economic safety of the enterprise are outlined. Based on the orientation of logistics management to meet the needs of consumers, these are defined as security officers and managers for whom security entities prepare analytical reports on the information support of certain management decisions. It is substantiated that the achievement of a synergetic effect is possible due to the clear organization of changes in the system of accounting and analytical support, when, in accordance with the developed instructions, employees will allocate some information of interest to security entities and send it to protected information channels. Logistics management will allow the combination of traditionally disparate information flows into a single on a permanent basis. Changes in the management system of economic security of the enterprise should provide for the elimination of resistance from the heads of individual units to manage information flows within their sphere of influence. Practical value. The practical application of the established methodological principles will contribute to the further improvement of the economic security system in the conditions of each business entity.

Keywords: economic security of the enterprise, logistics management, information, accounting and analytical support, security, threat. 